\title{
Association between essential trace and toxic elements in scalp hair samples of smokers rheumatoid arthritis subjects
}

\author{
Hassan Imran Afridi ${ }^{\text {a,b }}$, Tasneem Gul Kazi ${ }^{\text {b }}$,Dermot Brabazon ${ }^{\text {a }}$, Sumsun Naher ${ }^{\text {a }}$ \\ a Mechanical \& Manufacturing Engineering, Dublin City University, Dublin, Ireland. \\ b National Center of Excellence in Analytical Chemistry, University of Sindh, Jamshoro, Pakistan
}

\begin{abstract}
The incidence of rheumatoid arthritis (RA) has been increased among people who possess habit of tobacco smoking. In the present study, zinc $(\mathrm{Zn})$, copper $(\mathrm{Cu})$, manganese $(\mathrm{Mn})$, lead $(\mathrm{Pb})$ and cadmium $(\mathrm{Cd})$ were determined in scalp hair samples of smokers and nonsmokers RA patients, residents of Dublin, Ireland. For comparison purposes scalp hair samples of age and sex matched healthy smokers and nonsmokers were also analyzed. The concentrations of understudied elements were measured by inductive coupled plasma atomic emission spectrophotometer, prior to microwave assisted acid digestion. The validity and accuracy of methodology was checked using certified reference material (NCS ZC 81002b) and by the conventional wet acid digestion method on the same certified reference material and on real samples. The mean hair $\mathrm{Zn}, \mathrm{Cu}$ and Mn contents were significantly lower in smokers and nonsmokers RA patients as compared to healthy individuals ( $\mathrm{p}=0.01-0.001)$. Whereas the concentrations of $\mathrm{Cd}$ and $\mathrm{Pb}$ were significantly higher in scalp hair samples of RA patients of both group ( $p<0.001)$. The referent smokers have high level of $\mathrm{Cd}$ and $\mathrm{Pb}$ in their scalp hair samples as compared to those had not smoking tobacco ( $\mathrm{p}<0.01$ ). The ratio of $\mathrm{Cd}$ and $\mathrm{Pb}$ to $\mathrm{Zn}, \mathrm{Cu}$ and $\mathrm{Mn}$ in scalp hair samples was also calculated. The $\mathrm{Cd} / \mathrm{Zn}$ ratio was higher in smoker RA patients with re-lated to nonsmoker RA and referents. This study is compelling evidence in support of positive associations between toxic elements, cigarette smoking, deficiency of essential trace elements and risk of arthritis.
\end{abstract}

Keywords:Rheumatoid arthritis, Scalp hair, Cigarette smokers, Elements, Inductive coupled, plasma atomic emission, Spectrophotometer.

\section{1- Introduction}

Rheumatoid arthritis (RA) is a long-term disease that leads to inflammation of the joints and surrounding tissues. The RA is a major public health problem in elderly persons. Among the many contributing agents that have been proposed to take part in the pathogenesis of this condition, trace and toxic elements have also been investigated (Yazar et al., 2005; Helgeland et al., 2000; Ala et al., 2009; Silverio Amancio et al., 2003).

A variety of trace elements are found in bone including iron, copper, zinc, manganese, fluoride, strontium and boron (Sandstrom and Walter, 1998). The participation of trace elements, especially copper, manganese and zinc, in the normal development and maintenance of the skeleton is, at least in part, related to their catalytic functions in organic bone matrix synthesis or in the functioning of cells of bone or cartilage (Grynpas, 1990). 
The role of Zn in healthy aging is particularly important as it pre-vents neoplastic cell growth, is involved in mitotic cell division, DNAand RNA repair. Zinc plays an important role in nucleic acid synthesis, transcription and translation as a cofactor for some of the enzymes in-volved and may therefore participate in a broad range of metabolic activities in bone. Zinc has also been shown to be required by enzymes which have specific functions in bone metabolism. Zinc constitutes a structural element of alkaline phosphatase (ALP), with four of its atoms being present in the enzyme. Zinc also stimulates ALP syn-thesis in osteoblasts and plays an important role in bone mineralization (Heath and Shaw, 2001).

Copper deficiency during fetal and postnatal development has been shown to produce skeletal abnormalities and fragility in various experimental animals including the rat, chick, pig, horse and rabbit (Dollwet and Sorenson, 1988). It has been investigated that $\mathrm{Cu}$ deficiency can impair the cross linking of collagen and elastin in the organic bone matrix (Jonas et al., 1993). Through this mechanism, $\mathrm{Cu}$ deficiency may lead to diminished tensile strength of bone (Jonas et al., 1993). The deficiency of $\mathrm{Cu}$ and $\mathrm{Zn}$ reduces the antioxidant activity of zinc- and coppercontaining proteins and en-zymes such as metallothioneins, ceruloplasmin and $\mathrm{Cu}-\mathrm{Zn}$-superoxide dismutase (Milanino et al., 1993).

Kuo (1999) study has investigated that that $\mathrm{Cu}, \mathrm{Zn}$ and $\mathrm{Mn}$ are key components of the two major superoxide dismutase enzymes which have been shown to fight against the reactive intermediaries that are linked to the joint damage in arthritis (Soylak and Kirnap, 2001: Kuo, 1999). Evans and Halliwell (2001) reported that mitochondrial

Mn superoxide dismutase (Mn-SOD) is the primary cellular defense against damaging superoxide radicals generated by aerobic metabolism and as a consequence of inflammatory disease. Elevated levels of Mn-SOD provide potent cytoprotective advantage during acute arthritic inflammation.

It has been reported in literature that reactive oxygen species play a key role in the etiology of RA (Cerhan et al., 2003; Sarban et al., 2005; Fautrel and Bourgeois, 2000; PiotrowskaJastrzcbska et al., 2002; Sarban et al., 2007) and that one of them is the superoxide radical, which is eliminated by superoxide dismutase - an enzyme containing zinc in its molecule (Tapiero and Tew, 2003). It has also been found that over $90 \%$ of this trace element present in erythrocytes is bound with carbonic anhydrase and superoxide dismutase (Mierzecki et al., DOI 10.1007/ s12011-010-8952-2).

Cigarette design has evolved considerably over the last few de-cades with the incorporation of new tobacco processes, papers, filters and several ingredients (flavor, humectants and casing materials), which either alone or in combination have the potential to modify the quantity and/or the quality of the smoke yielded (Kozlowski and Connor, 2002). The tobacco plant absorbs toxic elements most probably from the soil, fertilizers or pesticides (Wagner, 1993).

Other environmental factors that may influence the uptake of toxic elements by tobacco plants include the $\mathrm{pH}$ of soil, contaminated irri-gated water and sewage sludge used as fertilizers. Tobacco smoking delivers 87 organic carcinogens to the lungs, in addition to toxic ele-ments (Chiba and Masironi, 1992), which may partition into the smoke phase on combustion (Chiba 
and Masironi, 1992). Some of the toxic metals $(\mathrm{Cd}, \mathrm{Ni}$ and $\mathrm{Pb}$ ) readily pass from inhaled smoke to the bloodstream and may accumulate in specific organs, such as the kidney and liver (Csalari and Szantai, 2002). There are a few studies that have reported on the large variations of heavy metal/toxic ele-ments in the compositions of commercial tobacco products, which have tried to link smoking-related diseases with toxic elements de-rived from tobacco combustion (Klaus et al., 2001). The intake of trace and toxic elements may promote rheumatoid arthritis disorders by increasing oxidative stress, by catalyzing the production of reactive oxygen species or inhibiting their degradation, due to the deficiency of antioxidant elements ( $\mathrm{Zn}, \mathrm{Cu}$ and $\mathrm{Mn}$ ). The deficiency of essential nutrients, lack of homeostatic control or an excess intake of some toxic elements causes chronic physiological disorders, such as hypertension, cardiovascular disease and rheumatoid arthritis (Witte et al., 2005).

Determinations of trace elements in human tissues and fluids were used to obtain information on nutritional status for diagnosis of diseases, indication of systemic intoxication, and to obtain information on environmental exposure (Aydin and Soylak, 2007; Soylak and Dogan, 1996). In the majority of cases, whole blood, serum, plasma, and urine were analyzed (Kazi et al., 2008). Hair can provide a more permanent record of trace and toxic elements associated with normal and abnormal metabolism as well as toxic elements assimilated from the environment. In addition, hair is easily collected, conveniently stored, and easily treated. Therefore, the analysis of human hair has become an important way to understand any quantitative change in certain elements inside the body (Afridi et al., 2008). One of the most widely used analytical technique for different elements determination in biological and environmental materials is inductively coupled plasma atomic emission spectrometry (ICP-AES) due to its advantages over other analytical methods: simultaneous determination of many elements of interest, freedom from different chemical interferences and high detection power. The sensitivity of ICP-AES is lower than that of either Inductive coupled plasma mass spectrophotometer (ICP-MS) or atomic absorption graphite tube atomizer (AA-GTA), but ICP-AES can handle higher levels of total dissolved solids (TDS) than ICP-MS and is much faster than AA-GTA. The main advantage of microwave-assisted samples pretreatment is its requirement of small amount of mineral acids and a reduction in the production of nitrous vapors. Microwave systems keep blank levels low because only small volumes of reagents are required and allow more samples to be processed per hour than conventional digestion systems (Afridi et al., 2006).

As seen in the literature, the alterations in trace and toxic element concentrations in the scalp hair samples of RA patients are inconsistent and, to our knowledge, there are no available reports of the understudy elemental levels in smoker and nonsmokers RA patients. The aim and objective of our present study was to assess the concentrations of $\mathrm{Cd}, \mathrm{Cu}, \mathrm{Mn}, \mathrm{Pb}$ and $\mathrm{Zn}$ in the scalp hair samples of smoker RA patients. For comparative purposes, 26 non-rheumatoid arthritis individuals (smoker and nonsmoker) of the same age group (ranged $42-56$ years), socioeconomic status, localities and dietary habits were selected as referents. The elements under study were analyzed by inductive coupled plasma atomic emission spectrophotometer, after microwaveassisted acid digestion. 


\section{2- Materials and methods}

\subsection{Apparatus}

A Varian Liberty 220 (Mulgrave, Victoria, Australia) inductively coupled plasma atomic emission spectrometer with the axially viewed plasma was used for the analysis. The Liberty Series II ICP fea-tures a $40 \mathrm{MHz}$ free running RF generator, a $0.75 \mathrm{~m}$ Czerny-Turner monochromator with 1800 grooves/mm holographic grating used in up to four orders. The resolution of the spectrometer is typically $0.018 \mathrm{~nm}$ in 1 st order, $0.009 \mathrm{~nm}$ in $2 \mathrm{nd}$ order, 0.007 $\mathrm{nm}$ in 3rd order and $0.006 \mathrm{~nm}$ in 4th order. The instrument was controlled with a Dig-ital Equipment Corporation (DEC) Venturis computer with an Intel Pentium processor and Varian Plasma 96 software running under Microsoft Windows 95 operating system. The instrumental condi-tions are shown in Tables 1a-lb. A Hinari Life style (Elstree, Hertford-shire, England) domestic microwave oven (maximum heating power-of $800 \mathrm{~W}$ ) was used for digestion of the scalp hair samples. Acid-washed polytetrafluoroethylene (PTFE) vessels and flasks were used for preparing and storing solutions.

Table 1a

Measurement conditions for inductive coupled plasma atomic emission spectroscopy Liberty 220 ICP-AES.

\begin{tabular}{llllll}
\hline Parameters & $\mathrm{Cu}$ & $\mathrm{Zn}$ & $\mathrm{Mn}$ & $\mathrm{Pb}$ & $\mathrm{Cd}$ \\
\hline Wavelength (nm) & 327.396 & 213.8 & 259.373 & 220.553 & 226.502 \\
Height (mm) & 5 & 5 & 5 & 3 & 3 \\
Windows (nm) & 0.027 & 0.027 & 0.027 & 0.027 & 0.027 \\
$\quad$ (above the coil) & & & & & \\
Scan (nm) & 0.040 & 0.040 & 0.040 & 0.040 & 0.040 \\
Integration (s) & 3 & 3 & 3 & 3 & 3 \\
Replicates & 3 & 3 & 3 & 3 & 3 \\
Sample uptake (sec) & 30 & 30 & 30 & 30 & 30 \\
PMT (V) & 650 & 650 & 650 & 650 & 650 \\
Power (kW) & 1.10 & 1.10 & 1.10 & 1.10 & 1.10 \\
Plasma flow (L/min) & 15.0 & 15.0 & 15.0 & 15.0 & 15.0 \\
Auxiliary flow (L/min) & 1.50 & 1.50 & 1.50 & 1.50 & 1.50 \\
Pump speed (rpm) & 15 & 15 & 15 & 15 & 15 \\
Background mode & Dynamic & Dynamic & Dynamic & Dynamic & Dynamic \\
Max curve order & 1 & 1 & 1 & 1 & 1 \\
C.C. Limit & 0.995 & 0.995 & 0.995 & 0.995 & 0.995 \\
\hline
\end{tabular}

Table 1b

Liberty 220 common parameters.

\begin{tabular}{ll}
\hline Nebulizer type & V-groove \\
\hline Nebulizer pressure & $150 \mathrm{kPa}$ \\
Stabilization time & $10 \mathrm{~s}$ \\
Sample delay time & $30 \mathrm{~s}$ \\
Rinse time & $10 \mathrm{~s}$ \\
Pump-tube & Orange-orange (inlet) \\
& Blue-blue (outlet) \\
Snout purge & Off \\
Fast pump & On \\
\hline
\end{tabular}

Key: $\mathrm{s}=$ seconds, $\mathrm{kPa}=$ kilo Pascal, $\mathrm{L}=$ liter, $\mathrm{min}=$ minutes, $\mathrm{nm}=$ nanometer, $\mathrm{V}=$ volt. 


\subsection{Reagents and glass wares}

Ultrapure water obtained from ELGA Lab Water system (Bucks, UK) was used throughout the work. Concentrated nitric acid (65\%) and hydrogen peroxide (30\%) were obtained from Merck (Darmstadt, Germany), and checked for possible trace metal contamination. Working standard solutions of $\mathrm{Cd}, \mathrm{Cu}, \mathrm{Mn}, \mathrm{Pb}$ and $\mathrm{Zn}$ were prepared immediately prior to their use, by stepwise dilution of certified stan-dard solutions (1000 ppm) Fluka Kamica (Buchs, Switzerland), with 0.5 $\mathrm{M}$ HNO3. All solutions were stored in polyethylene bottles at $4{ }^{\circ} \mathrm{C}$. For the accuracy of methodology, the certified reference material (CRM), human hair NCSZN 81002b (Beijing, China), was used (Table 2). All glassware and plastic materials used were previously soaked for $24 \mathrm{~h}$ in $5 \mathrm{M}$ nitric acid, washed with distilled and finally rinsed with ultrapure water, dried, and stored in a class 100 laminar flow hoods.

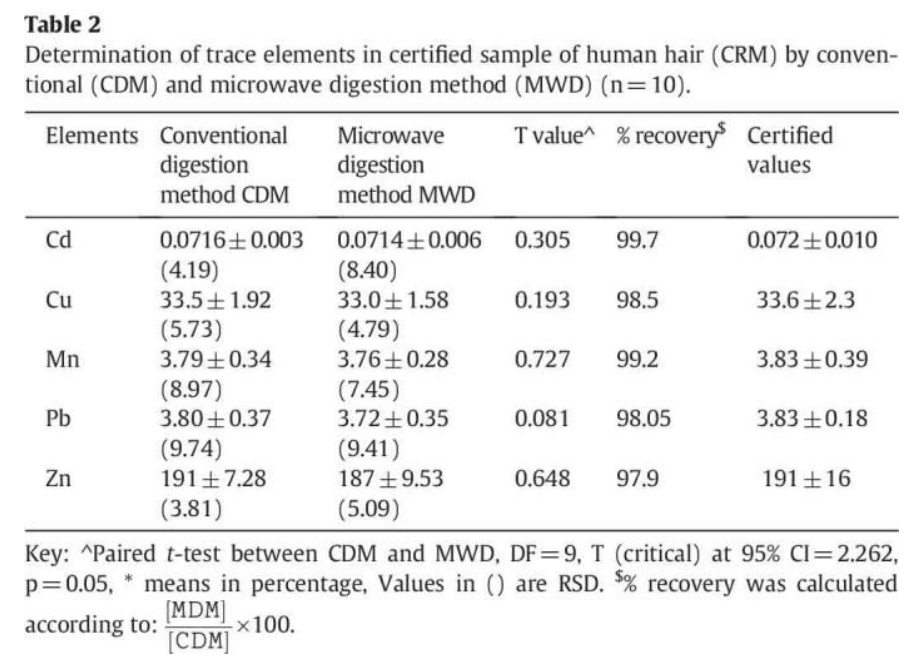

\subsection{Sample collection and pretreatment}

Before the start of this study, all referents and rheumatoid arthritis patients of both genders, age range $42-56$ years, were informed through a consent form by the administration about the aim of study, and all agreed to participate and signed the form. A questionnaire was also ad-ministered to them to collect details regarding physical data, ethnic origin, health, duration and frequency of smoking, dietary habits, age and consent. The RA patients were grouped according to their habits non-smokers (NSRA) and smoker patients (SRA). While control groups were also divided into two groups, referents nonsmokers (RNS) and smokers (RS) as shown in Table 3.

All the patients had active disease defined by the following criteria: erythrocyte sedimentation rate (ESR) of at least $30 \mathrm{~mm} / \mathrm{h}$, six or more tender joints, three or more swollen joints and morning stiff-ness of at least $30 \mathrm{~min}$ duration. Thirty patients were $\operatorname{IgM}$ rheumatoid factor positive. None of the patients had been treated with steroids, immunosuppressives or penicillamine in the 3 months before the study. They all were receiving non-steroidal antiinflammatory drugs (NSAIDs) (diclofenac sodium, $100 \mathrm{mg} /$ day). 


\begin{tabular}{|c|c|c|c|c|}
\hline \multirow[t]{2}{*}{ Parameters } & \multicolumn{2}{|c|}{ Referents (52) } & \multicolumn{2}{|c|}{ Arthritis patients (53) } \\
\hline & Male & Female & Male & Female \\
\hline \multicolumn{5}{|l|}{ Occupation } \\
\hline Labor & 12 & 11 & 12 & 14 \\
\hline Office workers & 15 & 14 & 15 & 12 \\
\hline \multicolumn{5}{|l|}{ Habits } \\
\hline Smokers & $14(52 \%)$ & $12(48 \%)$ & $15(56 \%)$ & $15(58 \%)$ \\
\hline Nonsmokers & $13(48 \%)$ & $13(52 \%)$ & $12(44 \%)$ & $11(42 \%)$ \\
\hline
\end{tabular}

Physical examinations were carried out in a basic health unit of Dublin, Ireland to measure participant's weight, height, blood pressure and biochemical data. For all patients and referents, anthropometric pa-rameters including weight, height and waist circumference were mea-sured using the standard protocols (Table 4). There were no statistically Significant differences between both groups of patients and referents with regard to height and weight The study protocol was approved by the local ethics committee of Dublin city university, Ireland.

\begin{tabular}{|c|c|c|c|c|}
\hline Parameters & RNS & RS & NSRA & SRA \\
\hline \multicolumn{5}{|l|}{ Male } \\
\hline Height $(\mathrm{cm})$ & $177.3 \pm 1.15$ & $178.6 \pm 1.03$ & $177.0 \pm 0.82$ & $176.6 \pm 1.37$ \\
\hline Weight (kg) & $75.3 \pm 1.24$ & $76.7 \pm 1.36$ & $73.9 \pm 1.03$ & $76.3 \pm 0.94$ \\
\hline $\begin{array}{l}\text { Waist circumference } \\
(\mathrm{cm})\end{array}$ & $77.4 \pm 0.92$ & $74.4 \pm 0.76$ & $76.9 \pm 1.16$ & $73.9 \pm 1.09$ \\
\hline BMI $\left(\mathrm{kg} / \mathrm{m}^{2}\right)$ & $23.9 \pm 0.60$ & $24.0 \pm 0.47$ & $23.6 \pm 0.56$ & $24.5 \pm 1.02$ \\
\hline Systolic BP (mm Hg) & $119.9 \pm 0.62$ & $120.4 \pm 0.49$ & $120.3 \pm 0.33$ & $120.5 \pm 0.45$ \\
\hline Diastolic BP (mm Hg) & $79.9 \pm 1.17$ & $80.2 \pm 0.68$ & $80.3 \pm 0.49$ & $80.5 \pm 0.34$ \\
\hline \multicolumn{5}{|l|}{ Female } \\
\hline Height $(\mathrm{cm})$ & $163.8 \pm 0.72$ & $163.5 \pm 0.58$ & $163.6 \pm 1.21$ & $163.5 \pm 1.06$ \\
\hline Weight (kg) & $60.9 \pm 1.13$ & $61.3 \pm 1.38$ & $60.1 \pm 0.52$ & $60.2 \pm 0.94$ \\
\hline $\begin{array}{l}\text { Waist circumference } \\
(\mathrm{cm})\end{array}$ & $63.3 \pm 1.09$ & $63.2 \pm 1.12$ & $63.4 \pm 0.69$ & $63.8 \pm 0.61$ \\
\hline BMI $\left(\mathrm{kg} / \mathrm{m}^{2}\right)$ & $22.7 \pm 1.14$ & $22.9 \pm 0.72$ & $22.4 \pm 0.57$ & $22.5 \pm 1.04$ \\
\hline Systolic BP (mm Hg) & $120.1 \pm 0.46$ & $120.4 \pm 0.32$ & $120.2 \pm 0.51$ & $120.7 \pm 1.01$ \\
\hline Diastolic BP (mm Hg) & $80.4 \pm 0.42$ & $80.5 \pm 0.58$ & $81.2 \pm 0.35$ & $80.9 \pm 0.48$ \\
\hline
\end{tabular}

The criteria of healthy subjects included no history of symptoms of any coronary disease documented in their medical notes. All control subjects underwent a routine medical examination. All patients and controls/referents were requested to complete an intervieweradministered questionnaire, concerning their demographic characteristics, age, health history, lifestyle habits, and diet. They gave written consent to participate in the study.

\subsection{Collection of scalp hair samples}

The hair samples $(-1.0 \mathrm{~g}$ each) were taken from the nape of the neck. Hair samples were put into separate plastic envelopes for each participant, on which the identification (ID) number of the participant was indicated. The plastic envelope of each subject was tightly sealed and attached to 
a questionnaire. Before analysis, each individual hair sample was cut into approximately $0.5-\mathrm{cm}-$ long pieces and mixed to allow a representative subsampling of the hair specimen. After cutting, each sample was washed with diluted Triton X-100: samples were then rinsed with distilled water and then with deionized water. The samples were then rinsed three times with acetone (Afridi et al., 2006). The sam-ples were then dried in an oven at $75 \pm 5{ }^{\circ} \mathrm{C}$ for $2 \mathrm{~h}$. Dried samples were stored separately in polyethylene bags.

\subsection{Microwave-assisted acid digestion}

A microwave-assisted digestion (MWD) procedure was carried out, in order to achieve a shorter digestion time. Duplicate samples of scalp hair $(200 \mathrm{mg})$ of each hypertensive patients and control individuals were directly placed into Teflon PFA flasks.

Two milliliters of a freshly prepared mixture of concentrated $\mathrm{HNO}_{3}-\mathrm{H}_{2} \mathrm{O}_{2}(2: 1, \mathrm{v} / \mathrm{v})$ was added to each flask and kept for $10 \mathrm{~min}$ at room temperature then placed in a covered PTFE container. This was then heated following a one-stage digestion program at $80 \%$ of total power $(800 \mathrm{~W})$. Complete digestion of scalp hair samples required 5-8 min. After the digestion, the flasks were left to cool and the resulting solution was evaporated to semidried mass to remove excess acid. About $5 \mathrm{ml}$ of $0.1 \mathrm{M}$ nitric acid was added to the residue and filtered through a Whatman no. 42 filter paper and diluted with deionized water up to $10.0 \mathrm{ml}$ in volumetric flasks. Blank extractions were carried through the complete procedure. Blanks and standard solutions were prepared in a similar acid matrix. The validity and efficiency of the MWD method was checked with certified values of human hair NCSZC $81002 \mathrm{~b}$ and with those obtained from conventional wet acid digestion method (Kazi et al., 2008).

\subsection{Analytical figures of merit}

Statistical analyses were performed using computer program Excel XL State (Microsoft Corp., Redmond, WA) and Minitab 13.2 (Minitab Inc., State College, PA). The Student's t-test was used to assess the significance of the differences in concentrations of elements among study subjects.

Calibration was performed with a series of $\mathrm{Cd}, \mathrm{Cu}, \mathrm{Fe}, \mathrm{Ni}, \mathrm{Pb}$ and $\mathrm{Zn}$ standards. Sensitivity (m) was the slope value obtained by least-square regression analysis of calibration curves based on absorbance signals. The equation $(n=5)$ for the calibration curves was as follows:

$$
\begin{aligned}
& Y=\left(1.28 \times 10^{-3} \pm 8.60 \times 10^{-5}\right)(\mathrm{Cd})+\left(1.30 \times 10^{-3} \pm 1.23 \times 10^{-4}\right), \mathrm{r}=0.999 \\
& Y=\left(4.38 \times 10^{-2} \pm 7.11 \times 10^{-3}\right)(\mathrm{Cu})+\left(4.39 \times 10^{-2} \pm 7.25 \times 10^{-3}\right), \mathrm{r}=0.999 \\
& Y=\left(7.12 \times 10^{-3} \pm 3.1 \times 10^{-5}\right)(\mathrm{Mn})+\left(6.98 \times 10^{-3} \pm 2.91 \times 10^{-5}\right), \mathrm{r} 2=0.999 \\
& Y=\left(1.875 \times 10^{-2} \pm 7.40 \times 10^{-4}\right)(\mathrm{Pb})+\left(1.91 \times 10^{-2} \pm 5.83 \times 10^{-3}\right) . \mathrm{r}=0.999 \\
& Y=\left(7.83 \times 10^{-2} \pm 1.18 \times 10^{-2}\right)(\mathrm{Zn})+\left(8.51 \times 10^{-2} \pm 1.03 \times 10^{-2}\right), \mathrm{r}=0.999
\end{aligned}
$$

where $\mathrm{Y}$ is the integrated absorbance, $\mathrm{r}$ is the regression and the con-centration range of As, $\mathrm{Cd}$, and $\mathrm{Pb}$ for calibration curve reached from the detection limits up to $100 \mu \mathrm{g}$. The limit of detection, equal to $0.0003 \mathrm{ng} / \mathrm{mg}, 0.01 \mathrm{ng} / \mathrm{mg}, 0.01 \mathrm{ng} / \mathrm{mg}, 0.0003 \mathrm{ng} / \mathrm{mg}$ and $0.01 \mathrm{ng} / \mathrm{mg}$ for Cd, $\mathrm{Cu}, \mathrm{Mn}, \mathrm{Pb}$, and $\mathrm{Zn}$ respectively, was defined as $3 \mathrm{~s} / \mathrm{m}$, 's' being the standard deviation 
corresponding to ten blank injections and ' $\mathrm{nn}$ ' the slope of the calibration graph. The quantification limits, defined as $10 \mathrm{~s} / \mathrm{m}$ were calculated as: $0.0009 \mathrm{ng} / \mathrm{mg}, 0.03 \mathrm{ng} / \mathrm{mg}, 0.03$ $\mathrm{ng} / \mathrm{mg}, 0.001 \mathrm{ng} / \mathrm{mg}$ and $0.04 \mathrm{ng} / \mathrm{mg}$ for $\mathrm{Cd}, \mathrm{Cu}, \mathrm{Mn}, \mathrm{Pb}$, and $\mathrm{Zn}$ respectively.

\section{3-Results}

In the study population, approximately $56-58 \%$ of RA patients and $48-52 \%$ of referents subjects of both genders were smokers. The physical parameters of RA patients and referents were obtained by a standard method as shown in Table 4 . Rheumatoid arthritis and healthy subjects were similar in age, height, body weight, and body mass index (BMI), as seen in Table 4 . The concentrations of $\mathrm{Zn}$ in the scalp hair samples of male RNS and RS were 33.5-38.2\% higher as compared with male smokers and nonsmokers arthritis patients $(\mathrm{p}=0.005-0.001)$. In the female cases, $\mathrm{Zn}$ levels in the scalp hair samples of NSRA and SRA patients were found to be $60-70 \%$ lower than those in referents of both group ( $\mathrm{p}<0.001)$. The concentrations of $\mathrm{Cu}$ in the scalp hair samples of females and males RNS and RS were 25.7-29.4\% higher than those values obtained from NSRA and SRA patients ( $\mathrm{p}<0.01-0.006$ ) (Table 5). The concentrations of Mn in the scalp hair samples of male RNS and RS were 43.4-47.0\% higher as compared with Mn values obtained in scalp hair samples of NSRA and SRA patients $(p<0.001)$. The same trend was observed in female case.

It was observed that the level of $\mathrm{Cu}, \mathrm{Mn}$ and $\mathrm{Zn}$ did not vary significantly in the scalp samples of referent smokers and nonsmokers indicating that the alteration of these trace elements in scalp hair samples was mainly due to disease state of the patients. An elevated level of $\mathrm{Cd}$ content was observed in the scalp hair of female NSRA and SRA patients $(\mathrm{p}=0.01-0.001)$. The same trend was observed in male cases (Table 5). The $\mathrm{Pb}$ concentration in the scalp hair samples of male referents of both group was found to be $24-29 \%$ lower than patients $(<0.05)$. The same trend was observed in females (Table 5). The unpaired student $t$ test at different degrees of freedom between RA patients and referents of both genders were calculated at different probabilities. Our calculated $t$,alue exceeds that of $t$-critical value at $95 \%$ confidence intervals, which indicated the significant dif-ferences between mean values of understudy elements in referents and RA patients ( $\mathrm{p}<0.001)$. The ratio of essential trace elements to toxic elements $(\mathrm{Zn}, \mathrm{Cu}, \mathrm{Mn} / \mathrm{Cd}$ and $\mathrm{Pb}$ ) was varied in the scalp hair samples of referents as compared to the RA patients of both genders (Table 6). 
Table 5

Essential trace and toxic elements in scalp hair samples of referent and Rheumatoid $\mathrm{Ar}$ thritis subjects $(\mu \mathrm{g} / \mathrm{g})$.

\begin{tabular}{|c|c|c|c|c|}
\hline Parameters & RNS & RS & NSRA & SRA \\
\hline \multicolumn{5}{|l|}{ Male } \\
\hline \multirow{3}{*}{ Copper } & $10.4 \pm 1.23$ & $10.9 \pm 0.93$ & $7.34 \pm 0.61$ & $8.09 \pm 0.82$ \\
\hline & $8.2-11.7^{*}$ & $9.95-11.9$ & $6.6-7.95$ & $7.15-8.96$ \\
\hline & $9.58,11.1^{\wedge}$ & $10.4-11.5$ & $7.02-7.72$ & $7.56-8.55$ \\
\hline \multirow[t]{3}{*}{ Manganese } & $3.41 \pm 0.65$ & $3.57 \pm 0.47$ & $1.93 \pm 0.28$ & $1.89 \pm 0.31$ \\
\hline & $2.89-4.10$ & $3.06-4.15$ & $1.58-2.36$ & $1.54-2.29$ \\
\hline & $3.09,3.78$ & $3.29,3.83$ & $1.79,2.08$ & $1.67,2.05$ \\
\hline \multirow[t]{3}{*}{ Zinc } & $203 \pm 7.53$ & $178 \pm 5.28$ & $135 \pm 9.42$ & $122 \pm 4.63$ \\
\hline & $194-211$ & $172-185$ & $124-145$ & $118-128$ \\
\hline & 196, 207 & 175,182 & 131,138 & 120,125 \\
\hline \multirow[t]{3}{*}{ Cadmium } & $0.68 \pm 0.07$ & $0.94 \pm 0.12$ & $2.13 \pm 0.37$ & $3.35 \pm 0.61$ \\
\hline & $0.59-0.78$ & $0.81-1.05$ & $1.79-2.56$ & $2.53-4.08$ \\
\hline & $0.64,0.72$ & $0.87,1.01$ & $1.95,2.31$ & $2.96,3.64$ \\
\hline \multirow[t]{3}{*}{ Lead } & $3.36 \pm 0.41$ & $3.75 \pm 0.28$ & $4.55 \pm 0.34$ & $5.62 \pm 0.87$ \\
\hline & $2.95-3.85$ & $3.49-4.05$ & $4.12-4.91$ & $4.75-6.45$ \\
\hline & $3.15,3.56$ & $3.60,3.89$ & $4.38,4.71$ & $5.22,6.08$ \\
\hline \multicolumn{5}{|l|}{ Female } \\
\hline \multirow[t]{3}{*}{ Copper } & $10.6 \pm 0.84$ & $10.7 \pm 0.99$ & $7.66 \pm 0.75$ & $7.95 \pm 0.95$ \\
\hline & $9.74-11.4$ & $9.84-11.9$ & $6.95-8.46$ & $6.96-8.92$ \\
\hline & $10.2,11.0$ & $10.4,11.2$ & $7.31,8.10$ & $7.48,8.43$ \\
\hline \multirow[t]{3}{*}{ Manganese } & $3.39 \pm 0.58$ & $3.55 \pm 0.62$ & $1.82 \pm 0.48$ & $1.74 \pm 0.25$ \\
\hline & $2.81-3.96$ & $2.89-4.21$ & $1.34-2.34$ & $1.46-2.05$ \\
\hline & $3.10,3.67$ & $3.22,3.83$ & $1.76,2.08$ & $1.56,1.90$ \\
\hline \multirow[t]{3}{*}{ Zinc } & $211 \pm 8.36$ & $167 \pm 5.82$ & $126 \pm 8.59$ & $117 \pm 7.28$ \\
\hline & $201-220$ & $159-173$ & $118-135$ & $108-125$ \\
\hline & 206,216 & 163,172 & 123,131 & 113,122 \\
\hline \multirow[t]{3}{*}{ Cadmium } & $0.59 \pm 0.09$ & $0.83 \pm 0.18$ & $1.73 \pm 0.37$ & $2.62 \pm 0.33$ \\
\hline & $0.48-0.69$ & $0.69-1.04$ & $1.53-2.22$ & $2.28-2.98$ \\
\hline & $0.54,0.63$ & $0.73,0.92$ & $1.56,1.93$ & $2.46,2.79$ \\
\hline \multirow[t]{3}{*}{ Lead } & $3.24 \pm 0.15$ & $3.59 \pm 0.16$ & $4.39 \pm 0.26$ & $5.42 \pm 0.51$ \\
\hline & $3.06-3.42$ & $3.32-3.78$ & $4.12-4.69$ & $4.87-5.96$ \\
\hline & $3.17,3.31$ & $3.51,3.67$ & $4.25,4.53$ & $5.17,5.67$ \\
\hline
\end{tabular}

Key: RNS $=$ referent nonsmokers, RS $=$ referent smokers, NSRA $=$ nonsmokers Rheumatoid arthritis patient, SRA = smokers Rheumatoid arthritis patient.

* Range.

$95 \%$ confidence interval.

Table 6

$\mathrm{Zn}, \mathrm{Cu}, \mathrm{Mn}$ vs. Cd and $\mathrm{Pb}$ Mole Ratios in scalp hair samples of referents and arthritis patients of both genders.

\begin{tabular}{llrrrr}
\hline Mole ratio & Genders & \multicolumn{1}{l}{ RNS } & \multicolumn{1}{l}{ RS } & NSRA & SRA \\
\hline $\mathrm{Zn} / \mathrm{Cd}$ & Male & 513.1 & 325.4 & 108.9 & 62.8 \\
& Female & 614.6 & 345.8 & 125.2 & 76.7 \\
$\mathrm{Zn} / \mathrm{Pb}$ & Male & 191.4 & 151.2 & 94.0 & 68.8 \\
& Female & 206.3 & 147.4 & 90.9 & 68.4 \\
$\mathrm{Cu} / \mathrm{Cd}$ & Male & 27.1 & 20.5 & 6.1 & 4.3 \\
& Female & 31.8 & 22.8 & 7.8 & 5.4 \\
$\mathrm{Cu} / \mathrm{Pb}$ & Male & 10.1 & 9.5 & 5.3 & 4.7 \\
& Female & 10.7 & 9.7 & 5.7 & 4.8 \\
$\mathrm{Mn} / \mathrm{Cd}$ & Male & 10.3 & 7.8 & 1.9 & 1.2 \\
& Female & 11.8 & 8.8 & 2.2 & 1.4 \\
$\mathrm{Mn} / \mathrm{Pb}$ & Male & 3.8 & 3.6 & 1.6 & 1.3 \\
& Female & 3.9 & 3.7 & 1.6 & 1.2 \\
\hline
\end{tabular}

Key: RNS $=$ referent nonsmokers, RS $=$ referent smokers, NSRA $=$ nonsmokers Rheumatoid arthritis patient, SRA = smokers Rheumatoid arthritis patient.

\section{4- Discussion}

This study provides data on the essential trace element $(\mathrm{Cu}, \mathrm{Mn}$ and $\mathrm{Zn})$ and toxic elements $(\mathrm{Cd}$ and $\mathrm{Pb}$ ) in scalp hair samples obtained from smoker, nonsmokers RA patients and referents of both genders with age ranged (42-56) years. 
Rheumatoid arthritis is an autoimmune disease, a disorder in which the body attacks its own healthy cells and tissues. When some-one has arthritis, the membranes around his or her joints become in-flamed and release enzymes that cause the surrounding cartilage and bone to wear away. In severe cases, other tissues and body organs also can be affected. The result shows that the level of $\mathrm{Zn}$ in scalp hair samples of rheumatoid arthritis patients was lower than referents. The skeleton is a major bone store of $\mathrm{Zn}$ and in humans approximately $30 \%$ of total body $\mathrm{Zn}$ is found in bone, probably bound to hydroxyapatite (Sauer and Wuthier, 1990). Zn deficiency is associated with delayed bone growth but few studies have been done to elucidate its potential role in bone turnover regulation. An increased $\mathrm{Zn}$ urinary excretion with unchanged $\mathrm{Zn}$ content in bone has been reported in postmenopausal osteoporosis (Honkanen et al., 1991).

It has been proposed that, since urinary $\mathrm{Zn}$ excretion is almost uninfluenced by variation in diet, urinary $\mathrm{Zn}$ excretion may be used as a marker of changes in bone metabolism (Relea et al., 1995). Zn supple-mentation was reported to decrease periarticular osteoporosis in rheumatoid arthritis patients (Honkanen et al., 1991). Defects in skeletal development have been reported in man due to zinc deficiency and also due to the acrodermatitis enteropathica, an inherited congenital disorder of zinc absorption (Alegre et al., 1984; Swann et al., 1981; Tudor et al., 2001).

It has been reported that forearm bone mineral content is correlated with zinc intake in premenopausal women, suggesting a possible role for zinc in the maintenance of bone mass (Angus et al., 1988). p-Alanyl-L-histidinato $\mathrm{Zn}$ has been shown to have a more potent effect than zinc sulfate on bone metabolism in experimental animals and this $\mathrm{Zn}$ chelate has been proposed as a possible treatment for osteoporosis (Yamaguchi, 1990). Our result showed that the mean concentration of $\mathrm{Cu}$ and $\mathrm{Mn}$ was found to be lower in the scalp hair samples of rheumatoid arthritis patients of both genders with related to referents (Table 5). Forestier (1949) was among the first to report that a $\mathrm{Cu}$ complex, Cupralene, was effective in the treatment of rheumatoid arthritis. Based on open studies, he concluded in 1949 that ' $\mathrm{Cu}$ salts are effective in the treatment of arthritis. They give better results than gold salts in the early stages of the disease. The clinical treatment with copper-containing agents, the clinical use of the anti-inflammatory copper dependent metalloenzyme superoxide dismutase (SOD), should also be commented upon. Bovine SOD has been shown to re-duce inflammation when given intraarticularly into the joints of arthritis patients. Ceruloplasmin and therapeutic $\mathrm{Cu}$ complexes have been shown to possess SOD-like activity. Hence the demonstrated physiological rise of ceruloplasmin in arthritis is suggested to repre-sent a protective response. Consistent with this, a lack of rise of ceruloplasmin may increase the risk of chronic disease, as seen in $\mathrm{Cu}$ - deficient animals with adjuvant arthritis (Conlan et al., 1990).

There is some evidence for a role of $\mathrm{Cu}$ deficiency in age-related osteoporosis. Serum copper levels of 46 elderly patients with fractures of the femoral neck were reported to be significantly lower than those of a group of controls matched for age and sex (Jorde et al., 2010). A significant positive correlation between serum $\mathrm{Cu}$ concentration and bone mineral density at the lumbar spine has been reported in a cross sectional study in postmenopausal women (Conlan et al., 1990). Eaton-Evans et al.(1996) have recently shown that $\mathrm{Cu}$ supplementation (3 mg/day for 2 
days) reduced the rate of loss of bone mineral density at the lumbar spine in 46- to 56-year-old women. This indicates that inadequate dietary copper intake may be a contributory factor to agerelated bone loss in this population group. Apps et al.(1992)have studied that Mn deficiency is unlikely but the effects of it are likely to be on the skin and bones primarily. The rareness of deficiency may be due to the fact that $\mathrm{Mg}$ can readily substitute for $\mathrm{Mn}$ in many reactions when the latter is not available. Effects of Mn deficiency in humans are not well defined. Limited information indicates that dermatitis, and possibly decreased levels of clotting proteins, decreased serum cholesterol, reddening of black hair and slowed growth of hair and nails may be consequences of Mn deficiency (Murray et al., 2000). Effects of Mn deficiency in animals include impaired growth, skeletal abnormalities, testicular degeneration in males, impaired reproductive function in females, ataxia, altered carbohydrate and lipid metabolism. Its deficiency also increased oxidation of mitochondrial membranes and reduced high density lipoprotein (ATSDR, 2001). The mean levels of $\mathrm{Pb}$ and $\mathrm{Cd}$ in the biological samples of referents of both genders were found to be lower than those recorded in arthritis patients (Table 5). Lead can increase osteoporosis and it may disrupt the normal formation of Calcium hydroxyapatite, thus critically weakening the bone (Skinner, 2000). Tandon et al.(2001) had reported that effects of $\mathrm{Pb}$ on humans include anemia, abdominal colic and gum wastage, while, $\mathrm{Cd}$ alters calcium and phosphorus metabolism, thus contributing to arthritis, osteoporosis and neuromuscular diseases. These effects may have been common in ancient times in such a severely polluted landscape. Lead has an exceptionally long half life in bone compared to other elements (Aufderheide, 1989). The many toxic elements, Arsenic, Cd, Cobalt and Antimony can deposit in bone from respiratory exposure (Oakberg et al., 2000). Toxic elements $(\mathrm{Cd}, \mathrm{Pb}$ and $\mathrm{Ni}$ ) may deplete glutathione and protein-bound sulfhydryl groups, resulting in the production of reactive oxygen species, such as superoxide anion, hydrogen peroxide and hydroxyl radical (Goyer, 1996).

Tobacco leaves naturally accumulate and concentrate relatively high levels of $\mathrm{Cd}, \mathrm{Ni}, \mathrm{Pb}, \mathrm{Fe}, \mathrm{Cu}$, and therefore smoking of tobacco is an important source of these metals exposure for smokers (Kazi et al., 2009). The total amount of carcinogens in cigarette smoke ranges from one to $3 \mathrm{pg}$ per cigarette (Csalari and Szantai, 2002). The country of origin and type of the product play major roles in determining the chemical composition of cigarette tobacco. It was investigated that one pack of cigarettes deposits 2-4 iLig $\mathrm{Cd}, 1-2 \mathrm{pg} \mathrm{Pb}$ and $\mathrm{Ni}$ into the lungs of a smoker, whereas some of the smoke passes into the air to be inhaled by smokers and nonsmokers alike (Hecht, 2003). It was also consistent with another study that smokers generally exhibit significantly higher $\mathrm{Cd}, \mathrm{Ni}$ and $\mathrm{Pb}$ body burdens than non-smokers (Hecht, 2003). The results suggested that $\mathrm{Cd}, \mathrm{Ni}, \mathrm{Pb}$ pose a hazard effects on essential trace elements homeostasis of various organs, co-exposure can pose a major threat, while consumption of ethanol may absorb much more $\mathrm{Cd}$ and $\mathrm{Pb}$ than their unexposed counterparts (Sharma et al., 1991).

In the past few years, increasing consideration has been given to interactions occurring in the organism between toxic elements and bio-elements essential for life. These interactions are complex and in-volve bio-elements such as zinc, copper, iron, selenium, calcium and 
toxic elements, including cadmium (Brzoska et al., 1997). The basis of Cd toxicity is its negative influence on enzymatic systems of cells, resulting from substitution of other essential elemental ions (mainly $\mathrm{Zn}, \mathrm{Cu}$ and $\mathrm{Ca}$ ) in metalloenzymes and its very strong affinity to bio-logical structures containing - SH groups, such as proteins, enzymes and nucleic acids (Stohs and Bagchi, 1995). The relevance of $\mathrm{Cd}, \mathrm{Pb}, \mathrm{Ni}, \mathrm{Cu}$ and $\mathrm{Fe}-\mathrm{Zn}$ interactions should be considered in the light of the general population exposure to toxic elements (Waalkes et al., 1992) and common deficiency of $\mathrm{Zn}$ in the world, mainly due to nutritional factors (Lonnerdal, 1993).

\section{5- Conclusion}

It can be concluded that impaired trace element metabolism may have a role in the pathogenesis and progression of arthritis. The really overlooked issue here is the dramatic impact of the toxic elements on human health. The excessive body burden of toxic elements may create the symptoms manifest in the form of muscle and joint com-plaints. The $\mathrm{Cd}$ and $\mathrm{Pb}$ interfere with the normal biochemical processes of $\mathrm{Mn}, \mathrm{Cu}, \mathrm{Zn}$ and other nutrients in the cells of human body. When these essential minerals in the body are disrupted by toxic elements, musculoskeletal symptoms such as muscle and joint pain commonly occur. The toxic elements impair the immune system, cause abnormal cell responses and may aggravate the sign and symptom of arthritis and other types of arthritis commonly called as "rheumatoid arthritis". It is necessary to add essential trace elements via food supplements. The results of this study provided guidance to clinicians and other professional investigating deficiency of essential trace elements and excessive level of toxic elements in biological samples of healthy and arthritis patients. This study also provides some support for the hypothesis that dietary intake or inhalation of toxic elements $(\mathrm{Cd}$ and $\mathrm{Pb})$, most probably through smoking cigarette, may increase the risk of rheumatoid arthritis and related disorders, which indicates that the causal link may be stronger among cigarette smokers. We propose that essential and toxic elemental measurements may be performed on patients reaching in the emergency department, to test whether the concentration of it may serve not only as markers of rheumatoid arthritis and its remedies but also as predictors of adverse outcomes.

The concentrations of essential trace and toxic elements in scalp hair samples of the Irish referent subjects were close to those reported from other European (Rodushkin and Axelsson, 2000; Reilly and Harrison, 1979; Nowak and Chmielnicka, 2000; Trojanowski et al., 2010; Sturaro et al., 1993; Goulle et al., 2005), American (Nagra et al., 1992; Ryan et al., 1978; Saiki et al., 2008; DeAntonlo et al., 1982) and Australian (McKenzie, 1979) countries (Table 7). The ele-mental concentrations of $\mathrm{Cd}$ and $\mathrm{Pb}$ in Pakistani referents were al-most higher than in European countries, which is in agreement with the studies which were done in Asian (Pasha et al., 2008, 2010; Shah et al., 2006; Khalique et al., 2005; Vishwanathan et al., 2002; Sukumar and Subramanian, 2003; Mehra and Juneja, 2005; Rao et al., 2002; Ashrafur et al., 2009; Sasmaz et al., 2003; Ulvi et al., 2002; Faghihian and Rahbarnia, 2002; Man and Zheng, 2002; Man et al., 1996; Sandstead et al., 1998), African (Nnorom et al., 2005; Hashem and Abed, 2007; Khuder et al., 2008; Eltayeb and Van-Grieken, 1989; Mortada et al., 2002) countries (Table 7). 
Table 7

Comparison of different elemental contents $(\mu \mathrm{g} / \mathrm{g})$ in scalp hair of people from various parts of the world.

\begin{tabular}{|c|c|c|c|c|}
\hline Authors & Elements & Age (years) & $\mathrm{N}$ & $\mathrm{x} \pm \mathrm{s}(\mu \mathrm{g} / \mathrm{g})$ \\
\hline \multicolumn{5}{|l|}{ Europe } \\
\hline \multicolumn{5}{|l|}{ Sweden } \\
\hline Rodushkin and & $\mathrm{Pb}$ & $1-75$ & 114 & $0.22-7.26$ \\
\hline \multirow[t]{4}{*}{ Axelsson $(2000)$} & $\mathrm{Cd}$ & $1-75$ & 114 & $0.010-0.356$ \\
\hline & $\mathrm{Zn}$ & $1-75$ & 114 & $68-198$ \\
\hline & $\mathrm{Cu}$ & $1-75$ & 114 & $8.5-96$ \\
\hline & $\mathrm{Mn}$ & $1-75$ & 114 & $0.080-2.41$ \\
\hline \multicolumn{5}{|l|}{ England } \\
\hline $\begin{array}{l}\text { Reilly and Harrison } \\
\text { (1979) }\end{array}$ & $\mathrm{Zn}$ & $16-25$ & 215 & $210-235$ \\
\hline \multicolumn{5}{|l|}{ Poland } \\
\hline Nowak and & $\mathrm{Pb}$ & 25-39 years & 624 & $4.8-5.7$ \\
\hline \multirow[t]{4}{*}{ Chmielnicka(2000) } & $\mathrm{Cd}$ & $25-39$ years & 624 & $0.56 \pm 2.3$ \\
\hline & $\mathrm{Zn}$ & 25-39 years & 624 & $132.7 \pm 135.7$ \\
\hline & $\mathrm{Cu}$ & 25-39 years & 624 & $7.2 \pm 6.2$ \\
\hline & $\mathrm{Mn}$ & 25-39 years & 624 & $2.5 \pm 2.2$ \\
\hline \multirow{4}{*}{$\begin{array}{l}\text { Trojanowski et } \\
\text { al.(2010) }\end{array}$} & $\mathrm{Pb}$ & $26-50$ & 109 & $3.71 \pm 0.29$ \\
\hline & $\mathrm{Cd}$ & & 109 & $0.401 \pm 0.035$ \\
\hline & $\mathrm{Pb}$ & $51-75$ & 121 & $3.88 \pm 0.35$ \\
\hline & $\mathrm{Cd}$ & & 121 & $0.260 \pm 0.022$ \\
\hline \multicolumn{5}{|c|}{$121-0.20010 .022$} \\
\hline \multirow[t]{3}{*}{ Sturaro et al.(1993) } & $\mathrm{Cu}$ & 21-60 years & 50 & $10-21$ \\
\hline & $\mathrm{Zn}$ & $21-60$ years & 50 & $171-314$ \\
\hline & $\mathrm{Pb}$ & 21-60 years & 50 & $6.5-8.7$ \\
\hline \multicolumn{5}{|l|}{ France } \\
\hline \multirow[t]{4}{*}{ Goulle et al.(2005) } & $\mathrm{Cu}$ & $40-60$ years & 45 & $9.0-61.3$ \\
\hline & $\mathrm{Zn}$ & $40-60$ years & 45 & 129-209 \\
\hline & $\mathrm{Pb}$ & $40-60$ years & 45 & $0.13-4.57$ \\
\hline & $\mathrm{Cd}$ & 40-60 years & 45 & $0.004-0.17$ \\
\hline \multicolumn{5}{|l|}{ Netherland } \\
\hline $\begin{array}{l}\text { lyengar and Wolttlez } \\
\text { (1988) }\end{array}$ & $\mathrm{Zn}$ & 21-60 years & 50 & $176 \pm 38$ \\
\hline \multicolumn{5}{|l|}{ South America } \\
\hline Nagra et al.(1992) & $\mathrm{Cd}$ & 22-59 years & 50 & $31.6 \pm 38$ \\
\hline Ryan et al.(1978) & $\mathrm{Zn}$ & 20-55 years & 42 & $108-357$ \\
\hline \multicolumn{5}{|l|}{ North America } \\
\hline Saiki et al.(2008) & $\mathrm{Zn}$ & $50-70$ years & 50 & $45-162$ \\
\hline & $\mathrm{Zn}$ & $71-87$ years & 50 & $30-202$ \\
\hline $\begin{array}{l}\text { DeAntonlo et } \\
\text { al.(1982) }\end{array}$ & $\mathrm{Zn}$ & $15-35$ years & 67 & $90-294$ \\
\hline Australia & & & & \\
\hline McKenzie(1979) & $\mathrm{Zn}$ & 16-56 years & 118 & $189 \pm 24$ \\
\hline Asia & & & & \\
\hline Pakistan & & & & \\
\hline Pasha et al.(2008) & $\mathrm{Pb}$ & $15-94$ years & 86 & $\begin{array}{l}14.62 \pm 8.01 \\
(0.577-31.8)\end{array}$ \\
\hline & $\mathrm{Cd}$ & $15-94$ years & 86 & $\begin{array}{l}2.13 \pm 1.74 \\
(0.196-9.17)\end{array}$ \\
\hline & $\mathrm{Zn}$ & $15-94$ years & 86 & $\begin{array}{l}154.2 \pm 117.1 \\
(12.4-729.2)\end{array}$ \\
\hline & $\mathrm{Cu}$ & $15-94$ years & 86 & $\begin{array}{l}22.35 \pm 12.9 \\
(3.27-73.6)\end{array}$ \\
\hline & $\mathrm{Mn}$ & $15-94$ years & 86 & $\begin{array}{l}1.69 \pm 1.02 \\
(0.10-4.83)\end{array}$ \\
\hline Pasha et al.(2010) & $\mathrm{Pb}$ & 37-65 years & 37 & $15.50 \pm 8.11$ \\
\hline & $\mathrm{Cd}$ & $37-65$ years & 37 & $1.675 \pm 1.13$ \\
\hline & $\mathrm{Zn}$ & 37-65 years & 37 & $140.7 \pm 79.5$ \\
\hline & $\mathrm{Cu}$ & $37-65$ years & 37 & $21.1 \pm 5.73$ \\
\hline Shah et al.(2006) & $\mathrm{Pb}$ & 3-54 years (Pakistan) & 62 & $15.97 \pm 5.56$ \\
\hline & & 3-54 years (Libya) & 62 & $24.95 \pm 8.69$ \\
\hline & $\mathrm{Cd}$ & 3-54 years (Pakistan) & 62 & $0.38 \pm 0.186$ \\
\hline & & 3-54 years (Libya) & 62 & $0.53 \pm 0.26$ \\
\hline & $\mathrm{Zn}$ & 3-54 years (Pakistan) & 62 & $226 \pm 53.7$ \\
\hline & & 3-54 years (Libya) & 62 & $190 \pm 34.0$ \\
\hline & $\mathrm{Cu}$ & 3-54 years (Pakistan) & 62 & $17.2 \pm 4.2$ \\
\hline & & 3-54 years (Libya) & 62 & $17.2 \pm 4.2$ \\
\hline & $\mathrm{Mn}$ & 3-54 years (Pakistan) & 62 & $1.93 \pm 0.94$ \\
\hline & & 3-54 years (Libya) & 62 & $1.73 \pm 1.09$ \\
\hline Khalique et al.(2005) & $\mathrm{Cd}$ & $41-50$ years $(\mathrm{M})$ & 18 & $0.283 \pm 0.126$ \\
\hline & & $51-60$ years & & $0.697 \pm 0.467$ \\
\hline & & $41-50$ years $(F)$ & 21 & $0.318 \pm 0.150$ \\
\hline & & $51-60$ years & & $0.732 \pm 0.714$ \\
\hline & $\mathrm{Zn}$ & $41-50$ years $(M)$ & 18 & $228.2 \pm 29.6$ \\
\hline
\end{tabular}

Table 7 (continued)

\begin{tabular}{|c|c|c|c|c|}
\hline Authors & Elements & Age (years) & $\mathrm{N}$ & $x \pm s(\mu g / g)$ \\
\hline & & $51-60$ years & & $153.6 \pm 37.0$ \\
\hline & & $41-50$ years $(F)$ & 21 & $319 \pm 59.1$ \\
\hline & & $51-60$ years & & $257 \pm 47.9$ \\
\hline & $\mathrm{Cu}$ & $41-50$ years $(\mathrm{M})$ & 18 & $15.38 \pm 2.71$ \\
\hline & & $51-60$ years & & $14.20 \pm 5.53$ \\
\hline & & $41-50$ years $(F)$ & 21 & $14.5 \pm 4.59$ \\
\hline & & $51-60$ years & & $26.2 \pm 8.69$ \\
\hline & Mn & $41-50$ years $(\mathrm{M})$ & 18 & $5.946 \pm 1.37$ \\
\hline & & $51-60$ years & & $5.364 \pm 1.05$ \\
\hline & & $41-50$ years $(F)$ & 21 & $10.52 \pm 4.87$ \\
\hline & & $51-60$ years & & $7.169 \pm 2.44$ \\
\hline \multicolumn{5}{|l|}{ India } \\
\hline \multirow{4}{*}{$\begin{array}{l}\text { Vishwanathan et } \\
\text { al.(2002) }\end{array}$} & $\mathrm{Pb}$ & $36 \pm 1.23$ years & 25 & $24.8 \pm 5.92$ \\
\hline & $\mathrm{Cd}$ & $36 \pm 1.23$ years & 25 & $5.12 \pm 3.41$ \\
\hline & $\mathrm{Zn}$ & $36 \pm 1.23$ years & 25 & $265.2 \pm 17.3$ \\
\hline & $\mathrm{Cu}$ & $36 \pm 1.23$ years & 25 & $9.70 \pm 1.98$ \\
\hline Sukumar and & $\mathrm{Pb}$ & $31-45$ years & 17 & $8.9 \pm 1.9$ \\
\hline \multirow[t]{9}{*}{ Subramanian(2003) } & & $46-60$ years & 11 & $4.5 \pm 2.8$ \\
\hline & $\mathrm{Cd}$ & $31-45$ years & 17 & $1.5 \pm 0.3$ \\
\hline & & $46-60$ years & 11 & $1.9 \pm 0.5$ \\
\hline & $\mathrm{Zn}$ & $31-45$ years & 17 & $87.0 \pm 1.9$ \\
\hline & & $46-60$ years & 11 & $112.8 \pm 25.3$ \\
\hline & $\mathrm{Mn}$ & $31-45$ years & 17 & $1.3 \pm 0.3$ \\
\hline & & $46-60$ years & 11 & $1.4 \pm 0.6$ \\
\hline & $\mathrm{Cu}$ & $31-45$ years & 17 & $27.8 \pm 7.5$ \\
\hline & & $46-60$ years & 11 & $17.2 \pm 4.2$ \\
\hline \multirow{5}{*}{$\begin{array}{l}\text { Mehra and Juneja } \\
(2005)\end{array}$} & $\mathrm{Pb}$ & $1-30$ years & 50 & $7.60 \pm 6.44$ \\
\hline & $\mathrm{Cd}$ & $1-30$ years & 50 & $0.32 \pm 0.21$ \\
\hline & $\mathrm{Zn}$ & $1-30$ years & 50 & $182.4 \pm 45.2$ \\
\hline & $\mathrm{Cu}$ & $1-30$ years & 50 & $8.48 \pm 2.06$ \\
\hline & Mn & $1-30$ years & 50 & $6.71 \pm 3.38$ \\
\hline \multirow[t]{5}{*}{ Rao et al.(2002) } & $\mathrm{Cd}$ & $17-60$ years & 20 & $0.12-0.61$ \\
\hline & $\mathrm{Cu}$ & $17-60$ years & 20 & $4.90-22.54$ \\
\hline & Mn & $17-60$ years & 20 & $0.62-6.94$ \\
\hline & $\mathrm{Zn}$ & $17-60$ years & 20 & $45.44-123.5$ \\
\hline & $\mathrm{Pb}$ & $17-60$ years & 20 & $0.75-4.1$ \\
\hline \multicolumn{5}{|l|}{ Bangladesh } \\
\hline \multirow[t]{2}{*}{ Ashrafur et al. (2009) } & $\mathrm{Zn}$ & - & 30 & $199.16 \pm 27.85$ \\
\hline & $\mathrm{Cd}$ & - & 30 & $0.47 \pm 0.32$ \\
\hline \multicolumn{5}{|l|}{ Turkey } \\
\hline \multirow[t]{2}{*}{ Sasmaz et al.(2003) } & $\mathrm{Pb}$ & - & 26 & $3.06 \pm 1.42$ \\
\hline & $\mathrm{Cd}$ & - & 26 & $0.67 \pm 0.33$ \\
\hline Ulvi et al.(2002) & $\mathrm{Zn}$ & $47.76 \pm 13.11$ years & 29 & 176.96 \\
\hline \multicolumn{5}{|l|}{ Iran } \\
\hline $\begin{array}{l}\text { Faghihian and } \\
\text { Rahbarnia, (2002) }\end{array}$ & $\mathrm{Zn}$ & $14-67$ years & 100 & $36-329$ \\
\hline \multicolumn{5}{|l|}{ Hong Kong } \\
\hline Man and Zheng & $\mathrm{Pb}$ & $20-50$ years & 30 & $12.04 \pm 7.0$ \\
\hline$(2002)$ & $\mathrm{Zn}$ & $20-50$ years & 30 & $184.85 \pm 60.89$ \\
\hline Man et al. (1996) & $\mathrm{Zn}$ & $30-69$ years & 95 & $355-503$ \\
\hline \multicolumn{5}{|l|}{ China } \\
\hline $\begin{array}{l}\text { Sandstead et al. } \\
\text { (1998) }\end{array}$ & $\mathrm{Zn}$ & $7-25$ years & 662 & $109-155$ \\
\hline Africa & & & & \\
\hline Nigeria & & & & \\
\hline Nnorom et al.(2005) & $\mathrm{Pb}$ & $1-30$ years & 46 & 63.6 \\
\hline & $\mathrm{Cd}$ & $1-30$ years & 46 & 1.0 \\
\hline & $\mathrm{Zn}$ & $1-30$ years & 46 & 128.6 \\
\hline & $\mathrm{Cu}$ & $1-30$ years & 46 & 121.0 \\
\hline Saudi Arabia & & & & \\
\hline $\begin{array}{l}\text { Hashem and Abed } \\
\text { (2007) }\end{array}$ & $\mathrm{Cd}$ & $20-25$ years & 20 & $0.035 \pm 0.007$ \\
\hline Syria & & & & \\
\hline Khuder et al.(2008) & $\mathrm{Pb}$ & $21-59$ years & 281 & $10.7 \pm 8.9$ \\
\hline & $\mathrm{Zn}$ & $21-59$ years & 281 & $260 \pm 113$ \\
\hline & $\mathrm{Cu}$ & $21-59$ years & 281 & $15.6 \pm 5.7$ \\
\hline Sudan & & & & \\
\hline Eltayeb and Van- & $\mathrm{Zn}$ & $30-50$ years & 35 & $89-170$ \\
\hline Grieken(1989) & $\mathrm{Pb}$ & $30-50$ years & 35 & $3-17$ \\
\hline Egypt & & & & \\
\hline Mortada et al.(2002) & $\mathrm{Pb}$ & $28-40$ years & 93 & $1.8-9.7$ \\
\hline & $\mathrm{Cd}$ & $28-40$ years & 93 & $0.08-0.82$ \\
\hline
\end{tabular}




\section{Acknowledgment}

Dr. Hassan Imran Afridi is grateful to Higher Education Commission (HEC) of Pakistan for providing the scholarships for the post doctoral research work. Dr. H.I. Afridi is also thankful to National Center of Excellence in Analytical Chemistry, University of Sindh, Jamshoro, Pakistan for the grant of sabbatical leave.

\section{References}

Afridi HI, Kazi TG, Kazi GH. Analysis of heavy metals in scalp hair samples of hypertensive patients by conventional and microwave digestion methods. Spectrosc Lett 2006;39: 20314.

Afridi HI, Kazi TG, Kazi N, Jamali MK, Arain MB, Jalbani N, et al. Evaluation of status of toxic metals in biological samples of diabetes mellitus patients. Diabetes Res Clin Pract 2008;80:280-8.

Ala S, Shokrzadeh M, Pur Shoja AM, Saeedi Saravi SS. Zinc and copper plasma concen-trations in rheumatoid arthritis patients from a selected population in Iran. Pak J Biol Sci 2009; 12:1041-4.

Alegre C, Baro J, Obach J. Zinc and rheumatic disease. Arthritis Rheum 1984;27:1073-4. Angus RM, Sambrook PN, Pocock NA, Eisman JA. Dietary intake and bone mineral den-sity. Bone Miner 1988;4:265-77.

Apps DK, Cohen BB, Steel CM. Biochemistry: a concise text for medical students. 5th ed. London: Bailliere Tindall; 1992.

Ashrafur RM, Kalam AMA, lqbal HM, Shalahuddin QMMA, Wasimul B, Farida B, et al. Zinc, manganese, calcium, copper, and cadmium level in scalp hair samples of schizophrenic patients. Biol Trace Elem Res 2009;127:102-8.

ATSDR. Guidance manual for the assessment of joint toxic action of chemical mixtures. Atlanta, GA: Agency for Toxic Substances and Disease Registry; 2001.

Aufderheide AC. Chemical analysis of skeletal remains. In: Iscan MY, Kennedy KAR, editors. Reconstruction of life from the skeleton. New York: Alan R. Liss; 1989. p. 237-60.

Aydin FA, Soylak M. A novel multi-element coprecipitation technique for separation and enrichment of metal ions in environmental samples. Talanta 2007;73:134-41.

Brzoska MM, Moniuszko-Jakoniuk J, Jurczuk M, Chraniuk M. The influence of cadmium on bone tissue in rats. Pol J Environ Stud 1997;6:29-32.

Cerhan JR, Saag KG, Merlino LA, Mikuls TR, Criswell LA. Antioxidant micronutrients and risk of rheumatoid arthritis in a cohort of older women. Am J Epidemiol 2003;157: 345-54.

Chiba M, Masironi R. Toxic and trace-elements in tobacco and tobacco-smoke. Bull WHO 1992;70:269-75.

Conlan D, Korula R, Tallentire D. Serum copper levels in elderly patients with femoral-neck fractures. Age Ageing 1990;19(3):212-4. 
Csalari J, Szantai K. Transfer rate of cadmium, lead, zinc and iron from the tobacco-cut of the most popular Hungarian cigarette brands to the combustion products. Acta Aliment 2002;31:279-88.

DeAntonlo SM, Katz SA, Schemer DM, Wood J. Anatomically-related variations in trace-metal concentrations in hair. Clin Chem 1982;28(12):2411-3.

Dollwet HHA, Sorenson JFJ. Roles of copper in bone maintenance and healing. Biol Trace Elem Res 1988;18:39-48.

Eaton-Evans J, Mcllwrath EM, Jackson WE, McCartney H, Strain JJ. Copper supplemen-tation and the maintenance of bone mineral density in middle-aged women. $J$ Trace Elem Exp Med 1996;9:87-94.

Eltayeb MAH, Van-Grieken RE. Preconcentration and XRF determination of heavy metals in hair from Sudanese populations. J Radioanal Nucl Chem 1989;131:331-42.

Evans P, Halliwell B. Micronutrients: oxidant/antioxidant status. Br J Nutr 2001;85 (Suppl. 2):567-74.

Faghihian H, Rahbarnia H. Determination of trace elements in hair of some local popu-lation in Iran by instrumental neutron activation analysis. J Radioanal Nucl Chem 2002;251:427-30.

Fautrel B, Bourgeois P. Affections rheumatismales: generalites. Drugs 2000;59:1-9. Forestier. Copper and gold salts in rheumatoid arthritis. J Ann Rheum Dis 1949;8: 132-4.

Goulle JP, Mahieu L, Castermant J, Neveu N, Bonneau L, Laine G, et al. Metal and metal-loid multi-elementary ICP-MS validation in whole blood, plasma, urine and hair reference values. Forensic Sci Int 2005;153:39-44.

Goyer RA. Toxic effects of metals. In: Klaassen CD, editor. Casarett and Doull's toxicology: the basic science of poisons, vol. 5. New York: McGraw-Hill; 1996. p. 691-736.

Grynpas MD. Fluoride effects on bone crystals. J Bone Miner Res 1990;5:S169-75.

Hashem AR, Abed KF. Aluminum, cadmium and microorganisms in female hair and nails from Riyadh. Saudi Arabia J Med Sci 2007;7:263-6.

Heath DA, Shaw NJ. Calcium and bone metabolism. In: Brook C, Hindmarsh P, editors. Clinical pediatric endocrinology. 4th edn. Oxford: Blackwell Science; 2001. p. 377-89.

Hecht SS. Tobacco carcinogens, their biomarkers and tobacco-induced cancer. Nat Rev Cancer 2003;3:733-44.

Helgeland M, Svendsen E, Forre 0, Haugen M. Dietary intake and serum concentrations of antioxidants in children with juvenile arthritis. Clin Exp Rheumatol 2000;18: 637-41.

Honkanen VEA, Lamberg-Allardt CH, Vesterinen MK, Lehto JH, Westermarck TW, MetsaKetela TK, et al. Plasma zinc and copper concentrations in rheumatoid arthri-tis: influence of dietary factors and disease activity. Am J Clin Nutr 1991;54:1082-6.

lyengar V, Wolttlez J. Trace elements in human clinical specimens: evaluation of liter-ature data to identify reference values. Clin Chem 1988;34:474-81.

Jonas J, Burns J, Abel EW, Cresswell MJ, Strain JJ, Paterson CR. Impaired mechanical strength of bone in experimental copper deficiency. Ann Nutr Metab 1993;37: 245-52. 
Jorde R, Sneve M, Torjesen PA, Figenschau Y, Hansen JB, Grimnes G. No significant effect on bone mineral density by high doses of vitamin D3 given to overweight subjects for one year. Nutr J 2010;9:1-9.

Kazi TG, Afridi HI, Kazi N, Jamali MK, Arain MB, Jalbani N, et al. Distribution of zinc, copper and iron in biological samples of Pakistani myocardial infarction (1st, 2nd and 3rd heart attack) patients and controls. Clin Chim Acta 2008;389:114-9.

Kazi TG, Jalbani N, Arain MB, Jamali MK, Afridi HI, Sarfaraz RA, et al. Toxic metals distribution in different components of Pakistani and imported cigarettes by electro-thermal atomic absorption spectrometer. J Hazard Mater 2009;163:302-7.

Khalique A, Ahmad S, Anjum T, Jaffar M. A comparative study based on gender and age dependence of selected metals in scalp hair. Environ Monit Assess 2005;104: 45-57.

Khuder A, Bakir MA, Hasan R, Mohammad A. Determination of nickel, copper, zinc and lead in human scalp hair in Syrian occupationally exposed workers by total reflec-tion X-ray fluorescence. Environ Monit Assess 2008;143:67-74.

Klaus KA, Witte MB, Andrew L, Clark MA, John GF. Chronic heart failure and micronu-trients. J Am Coll Cardiol 2001;37:1765-74.

Kozlowski LT, Connor RJ. Cigarette filter ventilation is a defective design because of misleading taste, bigger puffs, and blocked vents. Tob Control 2002;11:140-50.

Kuo S. In vivo architecture of the manganese superoxide dismutase promoter. J Biol Chem 1999;274(6):3345-54.

Lonnerdal B. Dietary factors influencing zinc absorption. J Nutr 1993;130:1378-83. Man CK, Zheng YH. Analysis of trace elements in scalp hair of mentally retarded chil-dren. J Radioanal Nucl Chem 2002;253:375-7.

Man CK, Zheng YH, Mak PK. Trace element profiles in the hair of nasopharyngeal car-cinoma (NPC) patients. J Radioanal Nucl Chem Lett 1996;212:151-60.

McKenzie JM. Content of zinc in serum, urine hair and toenails of New Zealand adults. Am J Clin Nutr 1979;32:570-9.

Mehra R, Juneja M. Elements in scalp hair and nails indicating metal body burden in polluted environment. J Sci Ind Res 2005;64(2):119-24.

Mierzecki A, Strecker D, Radomska K. A pilot study on zinc levels in patients with rheu-matoid arthritis. Biol Trace Elem Res 2011. doi:10.1007/s12011-010-8952-2.

Milanino R, Frigo A, Bambara LM, Marrella M, Moretti U, Pasqualicchio M. Copper and zinc status in rheumatoid arthritis: studies of plasma, erythrocytes and urine, and their relationship with disease activity markers and pharmacological treatment. Clin Exp Rheumatol 1993;11:271-81.

Mortada WI, Sobh MA, El-Defrawy MM, Farahat SE. Reference intervals of cadmium, lead, and mercury in blood, urine, hair, and nails among residents in Mansoura City, Nile Delta, Egypt. Environ Res Sect A 2002;90:104-10.

Murray RK, Granner DK, Mayes PA, Rodwell VW. Harper's biochemistry. 25th ed. New York: Lange; 2000. 
Nagra MS, Pallah BS, Sahota GPS, Singh H, Sahota HS. A study of trace elements in scalp hair and fingernails of industrial workers of Ontario, Canada. J Radioanal Nucl Chem 1992;162(2):283-8.

Nnorom IC, Igwe JC, Ejimone JC. Multielement analyses of human scalp hair samples from three distant towns in southeastern Nigeria. Afr J Biotechnol 2005;4:1124-7.

Nowak B, Chmielnicka J. Relationship of lead and cadmium to essential elements in hair, teeth, and nails of environmentally exposed people. Ecotoxicol Environ Saf 2000;46:265-74.

Oakberg K, Levy T, Smith P. A method for skeletal arsenic analysis, applied to the chal-colithic copper smelting site of Shiqmim, Israel. J Archaeol Sci 2000;27:895-901.

Pasha Q Malik SA, lqbal J, Shaheen N, Shah MH. Comparative distribution of the scalp hair trace metal contents in the benign tumour patients and normal donors. Envi-ron Monit Assess 2008; 147:377-88.

Pasha Q Malik SA, Shaheen N, Shah MH. Investigation of trace metals in the blood plasma and scalp hair of gastrointestinal cancer patients in comparison with controls. Clin Chim Acta 2010;411:531-9.

Piotrowska-JastrzOska J, Mikota B, Motkowski R. Nutritional antioxidants in health and disease [Rola antyoksydantow iywieniowych w stanie zdrowia i choroby]. Terapia 2002;10:43-9.

Rao KS, Balaji T, Rao TP, Babu Y, Naidu GRK. Determination of iron, cobalt, nickel, manganese, zinc, copper, cadmium and lead in human hair by inductively coupled plasmaa-tomic emission spectrometry. Spectrochim Acta Part B 2002;57:1333-8.

Reilly C, Harrison F. Zinc, Copper, Iron and Lead in Scalp Hair of Students and Non-Stu-dent Adults in Oxford. J Hum Nutr 1979;33(4):248-52.

Relea P, Revilla M, Ripoll E, Arribas I, Villa LF, Rico H. Zinc, biochemical markers of nutrition, and type I osteoporosis. Age Ageing 1995;24:303-7.

Rodushkin I, Axelsson MD. Application of double focusing sector field ICP-MS for multielemental characterization of human hair and nails. Part II. A study of the inhabi-tants of northern Sweden. Sci Total Environ 2000;262:21-36.

Ryan Douglas E, Holzbecher J, Stuart DC. Trace elements in scalp-hair of persons with multiple sclerosis and of normal individuals. Clin Chem 1978;24(11):1996-2000.

Saiki M, Alves ER, Jaluu 0, Sumita NM, Filho WI. Determination of trace elements in scalp hair of an elderly population by neutron activation analysis. J Radioanal Nucl Chem 2008;276(1):53-7.

Sandstead HH, Penland JG, Alcock NW, Dayal HH, Chen XC, Li JS, et al. Effects of repletion with zinc and other micronutrients on neuropsychologic performance and growth of Chinese children. Am J Clin Nutr 1998;68:470S-5S.

Sandstrom B, Walter P, (eds): Role of trace elements for health promotion and disease prevention, Bibl Nutr Dieta. Basel, Karger publication, Kevin Cashman, Albert Flynn, Trace elements and bone metabolism, 1998, No. 54, pp. 150-154. 
Sarban S, Kocyigit A, Yazar M, Isikan UE. Plasma total antioxidant capacity, lipid peroxidation, and erythrocyte antioxidant enzyme activities in patients with rheumatoid ar-thritis and osteoarthritis. Clin Biochem 2005;38:981-6.

Sarban S, Isikan UE, Kocabey Y, Kocyigit A. Relationship between synovial fluid and plasma manganese, arginase, and nitric oxide in patients with rheumatoid arthritis. Biol Trace Elem Res 2007;115:97-106.

Sasmaz S, Uz E, Pinar T, Vural H, Eiri M, Ilihan A, et al. Hair lead and cadmium concentrations in patients with epilepsy and migraine. Neurosci Res Commun 2003;32: 107-14.

Sauer GR, Wuthier RE. Distribution of zinc in the avian growth plate. J Bone Miner Res 1990;5:S162.

Shah MH, Shaheen N, Khalique A, Alrabti AAA, Jaffar M. Comparative metal distribution in hair of Pakistani and Libyan population and source identification by multivariate analysis. Environ Monit Assess 2006;114:505-19.

Sharma G, Sandhir R, Nath R, Gill K. Effect of ethanol on cadmium uptake and metabolism of zinc and copper in rats exposed to cadmium. J Nutr 1991;121:87-91.

Silverio Amancio OM, Alves Chaud DM, Yanaguibashi G, Esteves Hilario MO. Copper and zinc intake and serum levels in patients with juvenile rheumatoid arthritis. Eur J Clin Nutr 2003;57:706-12.

Skinner HCW. In praise of phosphates, or why vertebrates chose apatite to mineralise their skeletal elements. Geol. Int. 2000;42:232-40.

Soylak M, Dogan M. Column preconcentration of trace amounts of copper on activated carbon from natural water samples. Anal Lett 1996;29:635-43.

Soylak M, Kirnap M. Serum copper and zinc concentrations of patients with rheumatoid arthritis from Kayseri-Turkey. Fresenius Environ Bull 2001;10:409-10.

Stohs SJ, Bagchi D. Oxidative mechanisms in the toxicity of metal ions. Free Radic Biol Med 1995;18:321-36.

Sturaro A, Parvoli G, Doretti L Simultaneous determination of trace metals in human hair by dynamic ion-exchange chromatography. Anal Chim Acta 1993;274:163-70.

Sukumar A, Subramanian. Elements in the hair of non-mining workers of a lignite open mine in Neyveli. Ind Health 2003;41(2):63-8.

Swann JC, Reynolds IL Galloway WA. Zinc metalloenzyme properties of active and latent collagenase from rabbit bone. Biochem J 1981;195:41-9.

Tandon SK, Chatterjee M, Bhargava A, Shukla V, Bihari V. Lead poisoning in Indian silver refiners. Sci Total Environ 2001;281:177-82.

Tapiero H, Tew KD. Trace elements in human physiology and pathology: zinc and metallothioneins. Biomed Pharmacother 2003;57:399-411.

Trojanowski P, Trojanowski J, Antonowicz J, Bokiniec M. Lead and cadmium content in human hair in central Pomerania (northern Poland). J Elementol 2010;15(2): 363-84.

Tudor R, Zalewski PD, Ratnaike RN. Zinc in health and chronic disease. Scand J Rheuma-tol 2001;30:208-12. 
Ulvi H, Yigiter R, Yoldas TS, Dolu Y, Var A, Mungen B. Magnesium, zinc and copper con-tents in hair and their serum concentrations in patients with epilepsy. Eastern J Med 2002;7:315 .

Vishwanathan H, Hema A, Edwin D, Usha Rani MV. Trace metal concentration in scalp hair of occupationally exposed autodrivers. Environ Monit Assess 2002;77: 149-54.

Waalkes MP, Coogan TP, Barter RA. Toxicological principles of metal carcinogenesis with special emphasis on cadmium. Crit Rev Toxicol 1992;22:175-201.

Wagner GJ. Accumulation of cadmium in crop plants and its consequences to human health. Adv Agron 1993;51:173-212.

Witte KKA, Nikitin NP, Parker AC, von Haehling S, Volk HD, Anker SD, et al. The effect of micronutrient supplementation on quality-of-life and left ventricular function in elderly patients with chronic heart failure. Eur Heart J 2005;26:2238-44.

Yamaguchi M. (3-alanyl-L-histidinato zinc and bone resorption. Gen Pharmacol-Vasc S 1990;26:1179-83.

Yazar M, Sarban S, Kocyigit A, Isikan UE. Synovial fluid and plasma selenium, copper, zinc, and iron concentrations in patients with rheumatoid arthritis and osteoar-thritis. Biol Trace Elem Res 2005;106:123-32. 